

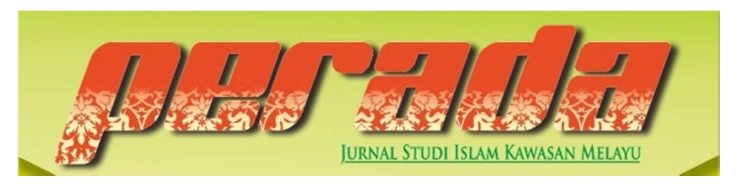

Perada: Jurnal Studi Islam Kawasan Melayu

ISSN 2656-7202 (P) ISSN 2655-6626 (0)

Volume 3 Nomor 1, Januari-Juni 2020

DOI: https://doi.org/10.35961/perada.v3i1.78

\title{
PERANAN PERSATUAN MUBALLIGH BATAM (PMB) TERHADAP TOLERANSI BERAGAMA DI KOTA BATAM KEPULAUN RIAU
}

\author{
Fauzi \\ STAIN Sultan Abdurrahman Kepulaun Riau \\ fauzi@stainkepri.ac.id
}

\begin{abstract}
ABSTRAK
Artikel ini bertujuan untuk melihat bagaimana peranan Persatuan Muballigh Batam (PMB) terhadap kehidupan beragama di Kota Batam dengan metode telaah pustaka dan wawancara dengan pihak-pihak terkait. Batam sebagai daerah metropolitian dihuni beraneka suku dan beragam pemeluk agama sehingga sangat rentan sekali terjadi gesekan dengan alasan keagamaan. Meskipun setiap agama mengajarkan pada kedamaian, namun pemahaman dari setiap pemeluknya bisa menimbulkan perbedaan pendapat sehingga konfelik bisa muncul di intra umat beragama itu sendiri dan di luarnya. Dalam hal ini, PMB sebagai salah satu organisasi yang mewadahi para penceramah memiliki andil dalam menjaga kedamaian di Batam. Dari hasil penelitian ini, PMB sering terlibat dalam hal sikap intoleransi keagamaan dengan memberikan penjelasan dan masukan kepada pihak-pihak terkait. Bahkan apabila suatu sikap terdapat kasus yang intoleran, PMB menyarankan agar kasus ditindaklanjuti secara bijak oleh pihak terkait agar tidak menimbulkan ekses yang berkepanjangan. PMB menegaskan bahwa anggotanya wajib perpaham ahlussunah wal jamaah dengan mengakui adanya sifat Allah dan anggotanya wajib menjadi tauladan di lingkungan masing-masing.
\end{abstract}

ABSTRACT: This article aims to see how the role of the Persatuan Muablligh Batam (PMB) on religious life in Batam City by means of literature review and interviews with related parties. Batam as a metropolitan area is inhabited by various ethnic groups and various religious adherents so that it is very vulnerable to friction for religious reasons. Although every religion teaches peace, the understanding of each adherent can lead to differences of opinion so that conflict can arise within the religious community itself and outside it. In this case, PMB as one of the organizations that accommodates the lecturers has a role in maintaining peace in Batam. From the results of this study, PMB is often involved in religious intolerance by providing explanations and input to related parties. Even if there is an attitude of intolerant cases, PMB recommends that the case be followed up wisely by the related parties so as not to cause prolonged excess. PMB emphasized that its members are obliged to understand ahlussunah wal jamaah by acknowledging the nature of Allah and its members are obliged to become role models in their respective environments.

Kata Kunci : Mubaligh Batam, Toleransi Beragama, Ablussunah 


\section{PENDAHULUAN}

Allah subhanabu wa ta'ala menciptakan manusia dengan perbedaan-perbedaan seperti yang ditegaskan-Nya di dalam surat al-Hujurat ayat 11 yang artinya, "wahai orangorang yang manusia sesunggubnya Kami telah menciptakan kamu dari seorang laki-laki dan seorang wanita bersuku-suku dan berbangsa-bangsa agar kamu saling mengenal. Sesunggubnya yang paling mulia di antara kamu adalab yang paling taqwa."

Dalam ayat yang lain Allah menegaskan, "Kalau Allah menghendaki, niscaya kamu dijadikan-Nya satu umat (saja), tetapi Allah hendak menguji kamu terhadap karunia yang telah diberikannya kepadamu, maka berlomba-lombalah berbuat kebajikan." (QS: 5: 48).

Dua ayat ini berbicara tentang perbedaan. Semua perbedaan yang ada adalah ketentuan Allah. Ujung ayat hanya menegaskan agar kita berlomba-lomba berbuat kebajikan. Namun Allah swt sudah menggariskan kebenaran (al-Quran) barang siapa yang mengikutinya dia akan selamat (QS: al Isra: ). Namun yang sangat tegas bahwa keyakinan itu tidak bisa dipaksakan dan tidak boleh. Berkeyakinan adalah hak dasar setiap orang karena itu ia murni dan tidak bisa dipaksakan. Karena itu Allah menegaskan dalam beberapa ayat al-Quran, "tidak ada paksaan dalam beragama" (QS: 2: 256). Allah juga menegaskan dalam surat alKafirun, "untuk kamu agama kamu, dan untuk kami agama kami". Potongan ayat ini juga mempersilakan berbeda keyakinan.

Dengan demikian jelas bahwa agama (keyakinan) adalah hak peribadi setiap orang dan Allah swt mempersilakan berbeda sekalipun Dia menjelaskan bahwa agama yang berasal dari Allah itu hanya Islam. (QS: 3: 18)

Keragaman atau pluralis dalam kehidupan bermasyarakat merupakan suatu yang fitrah. Dan suatu sistem tidak mungkin tercapai suatu kondisi yang beragam tanpa adanya perbedaan dan kemajemukan. Keragaman atau kemajemukan seperti perbedaan suku, agama, budaya, dan lainlain merupakan suatu kenyataan yang inheren dengan penciptaan manusia itu sendiri. ${ }^{1}$

Oleh karena itu dalam Pembukaan UUD 1945 pasal 29 ayat 2 telah disebutkan bahwa "Negara menjamin kemerdekaan tiap-tiap penduduk untuk memeluk agamanya sendiri-sendiri dan untuk beribadat menurut agamanya dan kepercayaannya masing-msing". Sebagai warga negara, sudah sewajarnya saling menghormati antar hak dan kewajiban demi menjaga keutuhan negara dan menjunjung tinggi sikap saling toleransi antar umat beragama.

Kota Batam merupakan salah satu kota yang terletak di Provinsi Kepulauan Riau, di mana masyarakat kota Batam merupakan masyarakat yang heterogen yang terdiri dari beragam suku, agama, dan golongan. Geogarifis kota Batam yang identik dengan kota industri membuat kota Batam sebagai kota yang menarik perhatian masyarakat luar daerah untuk datang dan mengadu peruntungan. Sehingga hari ini bisa dilihat penduduk kota Batam terdiri dari berbagai suku, di antara Melayu, Jawa, Batak, Minangkabau, Bugis, Sumbawa, Tionghoa dan lainya. Dengan berpayungkan Budaya Melayu dan menjunjung tinggi Bhinneka Tunggal Ika sebagai falsafah bangsa. Selain itu dari aspek Agama yang menjadi privasi setiap individu di Kota Batam juga sangat beragam, jika dilihat persentase 2017 di kota Batam, agama Islam sebagai mayoritas, dengan persentase jumlah penganut $71.32 \%$, dari 1.038.849 jiwa penduduk kota 2017. Diikuti oleh penganut Kristen Protestan

${ }^{1}$ Badri Khaeruman, Moralitas Islam (Bandung: Pustaka Setia, 2004), h. 188. 
sebanyak 18.35\%, Budha $6.78 \%$, Katolik $3.33 \%$, hindu $0,07 \%$, konghucu $0,10 \% .^{2}$

Dalam rangka memelihara keberagaman tersebut masing-masing individu, kelompok dan golangan masyarakat semuanya memiliki peran penting dalam mewujudnya kota Batam sebagai kota yang damai dan tenteram di tengah perbedaan, sehingga potensi yang ada di kota Batam sangat bergantung pada keamanan dan kenyamanan tersebut. Perlunya mewujudkan kerukunan antar umat beragama di kota Batam agar terciptanya satu konsep hidup bernegara yang mengikat semua anggota kelompok sosial yang berbeda agama guna menghindari "ledakan konflik antar umat beragama yang terjadi tiba-tiba". Di kota Batam begitu banyak organisasi keagamaan, baik dari internal agama itu sendiri maupun gabungan dari tiap-tiap agama yang ada, seperti Forum Kerukunan Umat Beragama (FUKB), kemudian di kalangan internal keagamaan masing-masing terbentuk pula organisasi seperti, Lembaga Pengembangan Dharma Gita (LPDG), Badan Kerjasama Antar Gereja Kota Batam (BKAG), Organisasi keagamaan agama Katolik, Paroki Kerahiman Ilahi Tiban, Pandita Sabha Budha Dharma Indonesia (PSBDI), Majelis Agama Konghucu Indonesia, dan ada pula PMB (Persatuan Muballigh Kota Batam) untuk kalangan internal islam. Tujuan dari terbentuknya organisasiorganisasi ini di antaranya secara umum sebagai pedoman bagi hehidupan beragama untuk mengatur tata cara hubungan antara manusia dengan sesama manusia dan tuhan, kemudian sebagai pedoman pengungapan persaudaraan di dalam suatu agama, yang mewajibkan berbuat baik terhadap sesama manusia. ${ }^{3}$

\footnotetext{
'Https://Batam.Go.Id/Profil/Sejarah', diangkes pada 25/06/2019, pukul 22.00 WIB.

3 'Https:/ /Www.Seputar Pengetahuan.Co.Id'.
}

Organisasi ini sudah cukup lama berkembang di kota Batam, jika dilihat dari nilai-nilai yang menjadi tujuan dari berdirinya organisasi tersebut diantaranya, pertama; dimana kehadiran organisasi PMB mampu memberi wawasan persatuan muballigh Kota Batam dalam merefleksikan cita-citanya senantiasa menyesuaikan diri dengan perkembangan dunia. Kedua; kehadirannya maupun membuat situasi menjadi indah dan damai. Ketiga, PMB Batam untuk mewujutkan masyarakat sejahtera lahir dan batin suasana madani dan penuh peradaban. Keempat, PMB kota Batam merupakan organisai lokal yang memposisikan diri sebagai mitra daerah dalam mengembangkan Batam. ${ }^{4}$

Dengan demikian untuk mengukur peran serta Persatuan Mubaligh Kota Batam dalam rangaka mewujudkan kota Batam sebagai Kota yang damai dan saling menghormati dalam bingkai toleransi beragama di Kota Batam Kepulaun Riau, penulis merasa perlu meneliti tentang "Peranan PMB (Persatuan Muballigh Kota Batam) terbadap toleransi beragama di kota Batam."

\section{TOLERANSI DALAM BEBERAPA KAJIAN}

Istilah toleransi adalah istilah modern, baik dari segi nama maupun kandungannya. ${ }^{5}$ Istilah ini pertama kali lahir di Barat, di bawah situasi dan kondisi politis, sosial dan budayannya yang khas. Toleransi berasal dari bahasa latin yaitu tolerantia. Kata ini berasal dari bahasa Inggris tolerance atau dalam bahasa Latin "tolerantia", artinya dengan

\footnotetext{
4 'Persatuan Muballigh Kota Batam', Wikipedia bahasa Indonesia, ensiklopedia bebas, 2019https://id.wikipedia.org/w/index.php?title=Per satuan_Muballigh_Kota_Batam\&oldid=15222609> [accessed 29 juni 2019].

5 Anis Malik Thoha, Tren Pluralisme Agama: Timjauan Kritis (Gema Insani, 2005), h. 212.
} 
sabar membiarkan sesuatu. ${ }^{6}$ Artinya kelonggaran, kelembutan hati, keringanan dan kesabaran. Toleransi merupakan sikap untuk memberikan hak sepenuhnya kepada orang lain agar menyampaikan pendapatnya, sekalipun pendapatnya salah dan berbeda. ${ }^{7}$ Secara etimologi istilah tersebut juga dikenal dengan sangat baik di dataran Eropa, terutama pada revolusi Perancis. Hal ini sangat terkait dengan slogan kebebasan, persamaan, dan persaudaraan yang menjadi inti revolusi di Perancis. ${ }^{8}$

Menurut kamus umum Bahasa Indonesia, Toleransi yang berasal dari kata "toleran" berarti bersifat atau bersikap meneggang (menghargai, membiarkan, membolehkan), pendirian (pendapat, pandangan, kepercayaan, kebiasaan, dan sebagainya) yang berbeda dan atau yang bertentangan dengan pendiriannya. ${ }^{9}$ Bila pemaknaan ini dijadikan pegangan, maka "kerukunan" adalah sesuatu yang ideal dan didambakan oleh masyarakat manusia.

Dalam Kamus Kontemporer ArabIndonesia, kata toleransi berasal dari asal kata: سََّ yang berarti: memberikan, memberi izin, dan membolehkan. Jika kata سَّi )huruf mim nya berbaris dhammah), maka diartikan: toleran atau murah hati. Kata سَّمَ (buruf mim nya berbaris sukun) pun diartikan sebagai toleransi, kata ini juga memiliki banyak persamaan, = الصَّذر حْبُ = جَواَدكَريْْ (kelapangan dada, yang dermawan,

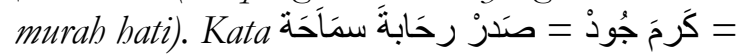
semuanya diartikan sebagai toleransi, kelapangan dada, dan kedermawanan. Adapun kata: ${ }^{2}$ "

6 Moh Ismail, 'Kritik Atas Pendidikan Toleransi Perspektif Multikulturalisme', At-Ta'dib, 7.2 (2012), h. 228.

7 Zuhairi Misrawi, 'Al Qur'an Kitab Toleransi: Inklusivisme', Pluralisme Dan Multikulturalisme, (Jakarta Selatan: Penerbit Fitrah. 2007), 2007, h. 161.

${ }^{8}$ Ibid.

${ }^{9}$ Daniel Haryono, Kamus Besar Bahasa Indonesia Edisi Terbaru (Jakarta: PT Media Pustaka Phoenix, 2012), h. 883.
سَماحَةُ di samping artinya toleransi, kata ini juga mengandung arti: iæin, legitimasi, lisensi, maaf, keadaan lapang dada dan kedermawanan. ${ }^{10}$

Di dalam Islam, istilah toleran disebut tasamub pada dasarnya tidak semata-mata selaras makna dengan kata tolerance, karena tasamub memberi arti memberi dan mengambil. Tasamuh berisi tindakan tuntutan dan penerimaan dalam batas-batas tertentu. Tasamub berisi harapan pada satu pihak untuk memberi dan mengambil secara sekaligus. Subjek yang melakukan tasamub dalam Islam dinamakan mutasamibin, yang berarti "pemaaf, penerima, menawarkan, pemurah sebagai tuan rumah kepada tamu". Dalam pelaksanaannya, orang yang melakukan tindakan tasamub ini tidak sepatutnya menerima saja sehingga menekan batasan hak dan kewajibannya sendiri. Dengan kata lain, perilaku tasamub dalam beragama memiliki pengertian untuk tidak saling melanggar batasan, terutama yang berkaitan dengan batasan keimanan (aqidab). Meskipun tasamuh memiliki pengertian seperti di atas, dalam banyak konteks, ia seringkali diselaraskan arti dengan kata "toleransi". Al-Qur'an tidak pernah menyebut-nyebut kata tasamuh atau toleransi secara tersurat dalam ayat-ayatnya. Namun, secara eksplisit al-Qur'an menjelaskan konsep toleransi dengan segala batasanbatasannya. Oleh karena itu, dalam implementasinya ayat-ayat yang menjelaskan tentang konsep toleransi dapat dijadikan rujukan dalam kehidupan. ${ }^{11}$

Secara terminologi, menurut Umar Hasyim, toleransi yaitu pemberian

10 Atabik Ali and Ahmad Zuhdi Muhdlor, Kamus Kontemporer Arab-Indonesia (Yayasan Ali Maksum, 1996), h. 1083-86.

11 Adeng Muchtar Ghazali, 'Toleransi Beragama Dan Kerukunan Dalam Perspektif Islam', Religious: Jurnal Studi Agama-Agama Dan Lintas Budaya, 1.1 (2016), 25-40 (h. 28) <https://doi.org/10.15575/rjsalb.v1i1.1360>. 
kebebasan kepada sesama manusia atau kepada sesama warga masyarakat untuk menjalankan keyakinannya atau mengatur hidupnya dan menentukan nasibnya masingmasing, selama dalam menjalankan dan menentukan sikapnya itu tidak melanggar dan tidak bertentangan dengan syarat-syarat atas terciptanya ketertiban dan perdamaian dalam masyarakat. ${ }^{12}$

Dalam Islam persaudaraan atau ukhwah merupakan salah satu ajaran yang mendapatkan perhatian penting, al-Qur'an menyebut kata yang mengandung kata ukhwah (persaudaraan) sebanyak 52 kali yang menyangkut berbagai persamaan, baikpersamaan keturunan, keluarga, masyarakat, bangsa bangsa dan agama. Secara umum di dalam Islam ukhwah dapat dibagi kedalam empat golongan. pertama ukhwah 'ubudiyyah, kedua ukhwah insaniyyah, ketiga ukhwah wathaniyah, dan yang ke empat ukhuwah fid din al Islam. Di mana tujuan dari ukhwah tersebut adalah bagaimana manusia saling merasa bersaudara, meskipun persaudaraan tersebut tidak berdasarkan hubungan kekeluargaan, tapi ada hubungan seiman, jika tidak ada hubungan seiman, maka manusia diperssaudarakan dengan bingkai kenegaraan, dan lebih jauh dari itu manusia dipersaudarakan karna sesama manusia. Esensi dari persaudaraan tersebut terletak pada kasih sayang dalam bentuk perhatiaan, kepedulian, saling menghormati dan saling menghargai antar sesama dalam rangka menggapai persatuan dan kesatuan sebagai Implementasi dari ajaran Islam.

Praktik toleransi atau kesadaran adanya kemajemukan atau pluralisme selain cukup jelas di dalam doktrin Islam, juga

12 Umar Hasyim, Toleransi Dan Kemerdekaan Beragama Dalam Islam Sebagai Dasar Menuju Dialog Dan Kerukunan Antar Agama: Sejarah Tolerasi Ile Toleransi Dan Intoleransi Agama Dan Kepercayaan Sejak Jaman Yunani (Bina Ilmu, 1979), h. 22. telah dipraktikkan dalam sejarah kehidupan umat Islam, sejak agama ini muncul di tanah Arab lebih kurang pada abad ke-7 M. Dengan kata lain, gambaran ideal potret toleransi atau kesadaran azas kemajemukan telah banyak dicontohkan nabi Muhammad dan para sahabatnya yang kemudian menjadi model bagi tata laku kehidupan masyarakat dan bernegara di kemudian hari. Gambaran ini secara original dapat dilihat dalam butirbutir "Piagam Madinah"13.

Nabi Muhammad sendiri tidak menganggap ajaran agama sebelum Islam sebagai ancaman. Islam adalah kontinuitas dari agama-agama sebelumnya. Allah berfirman agar Nabi Muhammad mengikuti agama Ibrahim, sebagaimana pula Isa datang menggenapi hukum Taurat. Dalam pandangan Islam semua nabi adalah. bersaudara. Bahkan nabi Muhammad pernah bersabda, "Tidak ada orang yang paling dekat bubungan kekerabatannya dengan Isa al-Masib ketimbang aku”. Ketika nabi Muhammad beserta pengikutnya mendapat intimidasi dari kaum Musyrik Makkah, Muhammad Saw. dan pengikutnya mengungsi ke Abbisyinia dan diterima baik oleh rajanya yang beragama Kristen. Demikian pula sebaliknya, ketika sejumlah tokoh Kristen yang berjumlah 60 orang berkunjung ke

13 Khusus tentang Piagam Madinah dapat dilihat dalam buku William Montgomery Watt, 'Islamic Political Thought', Edinburgh: Edinburgh University. Translation in French (1995), La Pensée Politique de l'islam. Paris: PUF, 1968; Ahmad Zainal Abidin, 'Piagam Nabi Muhammad Saw: Konstitusi Negara Tertulis Yang Pertama Di Dunia', Jakarta: Bulan Bintang, 1973; Pulungan J. Suyuthi, PrinsipPrinsip Pemerintahan Dalam Piagam Madinah: Ditinjau Dari Pandangan Alquran (Jakarta: LSIK, 1994); Ahmad Sukardja, Piagam Madinah Dan Undang-Undang Dasar 1945: Kajian Perbandingan Tentang Dasar Hidup Bersama Dalam Masyarakat Yang Majemuk (Penerbit Universitas Indonesia, 1995); Atau dalam Literatur yang Standard dalam Ibn Hisyam, Sirah Al-Nabi (Beirut: Dar Ihya al-Turas al „Arabiyy, t.t). 
Madinah yang dipimpin oleh Abdul Masih. Mereka diterima dengan sangat baik. Ketika itu nabi Muhammad beserta sahabatnya sedang melaksanakan sholat di masjid. Rombongan itu memakai jubah serban, pakaian yang juga lazim digunakan Muhammad saw. Ketika waktu kebaktian tiba, merekapun tidak mencari gereja. Nabi Muhammad memperkenankan rombongan melakukan kebaktian atau sembahyang di dalam masjid. ${ }^{14}$ Praktik toleransi atau kesadaran akan azas kemajemukan sebagaimana yang dicontohkan nabi kemudian diteruskan oleh para sahabat nabi sebagaimana dilakukan Umar bin Khattab ketika melakukan ekspansi ke wilayah Bizantium Kristen. Ketika wilayah ini ditaklukkan, Umar mengadakan perjanjian dengan uskup setempat yang berisi tentang jaminan Islam akan eksistensi Kristen di dalam kekuasaan Islam. Isi perjanjian tersebut adalah, "Dengan nama Allah yang Maha Pengasib lagi Maba Penyayang. Perjanjian ini diberikan Umar, Hamba Allah, dan Amir alMukminin, kepada penduduk Aelia. Dia (Umar) menjamin keamanan jiwa mereka dan harta-harta mereka, gereja-gereja dan salib-salib mereka dan kepada penganut agama Kristen. Gereja-gereja mereka tidaklah akan dijarah ataupun dibancurkan. atau harta benda dikurangi dalam bentuk apapun. Mereka (pemeluk Kristen) tidaklah akan dipaksa dalam bentuk apapun dalam kaitannya dengan agama mereka; dan mereka haruslab terpelihara dari bahaya. Dan tidak akan ada orang Yabudi yang dibenarkan bidup di tengah mereka." ${ }^{15}$ Prinsip keadilan, persamaan, dan kebebasan yang diberikan

14 Abd Moqsith Ghazali, Argumen Pluralisme Agama: Membangun Toleransi Berbasis al-Qur'an (Kata Kita, 2009).

15 Thomas Arnold, The Preaching of Islam: $A$ History of the Propagation of the Islamic Faith (Lahore: Sh. Muhammad Ashraf, 1961), h. 56-57; Alistair Duncan, The Noble Sanctuary (London: Longman Group, 1972), h. 22. oleh penguasa Islam kepada umat-umat lain ini yang kemudian menyebabkan umat Kristen tumbuh dan berkembang secara luas. Bahkan pada abad-abad pertama hijriah, mayoritas penduduk di dalam entitas politik Muslim adalah penganut Kristen. Situasi demikian tidak mereka dapati pada masa-masa sebelumnya seperti pada kekuasaan Kristen maupun Bizantium Yunani.

Prinsip-prinsip luhur azas toleransi atau kemajemukan tersebut juga dapat dijumpai pada hampir di wilayah-wilayah kekuasaan Islam lainnya, seperti anak benua India. Di wilayah ini para penganut, Hindu dan Budha mendapat hak yang sama sebagaimana yang diperoleh kaum Yahudi dan Nasrani. Ketika kekuasaan Islam berakhir, masyarakat tetap berada pada keyakinan semula. Hal ini membuktikan bahwa prinsip toleransi atau kerukunan tetap menjadi pegangan bagi para penguasa muslim.

\section{PMB DAN PERANANNYA DALAM MENJAGA TOLERANSI}

\section{A. Kelabiran dan Tujuan PMB}

Persatuan Muballigh Kota Batam adalah sebuah organisasi yang terbentuk Pada Tanggal 08 Jumadil Akhir 1420 H. atau bertepatan dengan 18 September 1999 M di kota Batam. ${ }^{16}$ Berdasarkan litreatur sejarah berdirinya Persatuan Muballigh Kota Batam (PMB), di mana sejatinya Organisasi ini merupakan kelanjutan dari organisasi sebelumnya yaitu MDI (Majlis Dakwah Islam) yang berdiri pada masa orde baru, namun setelah masa Orde baru berakhir organisasi ini berubah menjadi PMB. Tujuan dari perubahan itu adalah supaya organisasi ini tidak identik terhadap salah satu partai politik, kemudian di mana tujuan dari

16 Wawancara, Sudirman Dianto (Sekretaris PMB kota Batam), tanggal 28 Oktober 2019. 
perubahan itu supaya organisasi dakwah ini lebih terbuka untuk semua kalangan, artinya tidak hanya dari kalangan tertentu saja akan tetapi organisasi ini terbuka untuk semua golongan baik dari kalangan NU, Muhammadiyah, Tarbiah, al-Washliyah dan lainnya, tujuan bagaimana organisasi ini menjadi suatu wadah dakwah bagi umat Islam yang ada di kota Batam. Orgnisasi ini sudah cukup lama berkembang perkem-bangan umat Islam di kota Batam.

\section{B. Peran PMB Terbadap Toleransi Beragama di Kota Batam}

Indonesia adalah negara yang plural, namun pluralisme agama bukanlah kenyataan yang mengharuskan orang untuk saling menjatuhkan, saling merendahkan atau membanding-bandingkan antara agama satu dengan yang lain. Menempatkan posisi yang saling menghormati, saling mengakui dan kerjasama itulah yang harus dilakukan semua pemeluk agama. Sikap yang harus dimiliki oleh setiap umat dalam menempatkan berbagai perbedaan, yaitu hidup menghormati, memahami dan mengakui diri sendiri, tidak ada paksaan, tidak mementingkan diri sendiri maupun kelompok. ${ }^{18}$

Islam sebagai agama yang ramah telah menunjukkan nilai-nilai ajaran yang inklusif. Nilai-nilai universal Islam yang luhur dengan konsep rahmatan lil alamin memberikan distingsi tersendiri. Karena Islam tidak memihak pada Muslim saja, tetapi juga memberikan jaminan sosial pada pemeluk agama lain. Oleh karena itu dalam mewujudkan rasa nyaman di tengah peluralisme kehidupan, khususnya kota Batam maka PMB termasuk sebuah

17 Wawancara, Maryonono (Ketua Persatuan Muballigh Kota Batam),tanggal 25 Oktober 2019.

18 Elga Sarapung, 'Pluralisme, Konflik Dan Perdamaian', Yogyakarta: Pustaka Pelajar, 2002, h. 8. organisasi yang berperan dalam rangka menjaga kedamaian dan kenyamanan di tengah perbedaan.

Ada dua arah toleransi yang diemban oleh PMB. Pertama, toleransi intra. Pada perinsipnya PMB adalah organisasi Islam yang terbuka bagi setiap orang Islam yang ingin berpartisipasi dalam dakwah, tanpa memandang suku dan wadah apa mereka berasal. Konsep ini sudah sejak awal menjadi rumusan penting bagi berdirinya PMB. Salah seorang pendiri PMB, yang sekarang menjabat Rektor Universitas Batam, Prof. Dr. Chablullah Wibisono, adalah tokoh Muhammadiyah dan pernah menjadi Ketua Muhammadiyah Provinsi Kepulaun Riau sedangkan yang lain berasal dari alWashliyah (Drs. Zulkifli Aka, M. Si), Didi Suryadi (NU), H. Khudhry Syam (Tarbiyah), dan Efendy Asymawi (Nahdhtul Wathan). ${ }^{19}$ Untuk menjadi anggota juga demikian, maksudnya tanpa memandang dari organisasi apa ia berasal asal dengan tujuan dakwah Islam dan tidak memecah belah umat. Terhadap anggota pemecah belah umat tentu akan diproses oleh komite etik dan biasanya dikenakan teguran hingga sangsi. ${ }^{20}$ Seleksi penerimaan anggotapun agak selektif. Khususnya terhadap pelamarpelamar yang intoleran tidak akan diterima menjadi anggota PMB. Sebagai contoh, penerimaan calong anggota PMB tahun 2015 diikuti oleh 37 calon anggota. Di antara calon anggota yang menjalani tes tertulis itu ada seorang calon tamatan Yaman Utara. Dalam lembar jawaban yang menanyakan mengenai sifat-sifat yang wajib bagi Allah, jawabannya di luar perkiraan. Katanya, bagi saya, sifat-sifat Allah itu tidak ada. Dan tentu saja jawaban ini menjadi diskusi yang

19 Wawancara, H. Khudhry Syam, (Salah Seorang Pendiri PMB), tanggal 26 Oktober 2019.

20 Wawancara, Zulkarnaen Umar, $\mathrm{MH}$, (Ketua Umum PMB), periode 2014-2017. 
panjang bagi para penguji untuk memutuskan apakah calon ini diterima atau tidak. Dan setelah melalui beberapa pertimbangan, dipastikan bahwa calon itu ditolak. ${ }^{21}$ Hamdan menguraikan mengenai alasan penolakannya, menurut Hamdan, calon anggota semacam ini memiliki potensi jadi pemecah belah karena di Indonesia secara umum adalah berakidah dengan akidah Ahlussunnah waljamaah yang mengakui bahwa Allah memiliki sifat-sifat; sifat yang wajib, jaiz, dan mustahil. Sedangkan kelompok yang tidak mengakui sifat-sifat Allah adalah Mu'tazilah. Dengan demikian orang semacam itu tidak diperlukan di PMB.

Karena itu lambang PMB adalah bola dunia dihiasi oleh pelangi. Berdasarkan lambang PMB adalah gambar bola dunia di hiasi pelangi di sebelah atas dan disebelah bawah terhampar lautan, di tengah bola dunia terdapat peta Batam dengan kitab AlQur'an diposisi jantung Kota Batam di bawah gambar lautan tertulis "PERSATUAN MUBALLIGH KOTA BATAM" melingkar searah pelangi, diapit oleh tulisan "PMB" ditengahnya terdapat nilai atau filosofi dari lambang tersebut.

1. Gambar bola dunia mengambarkan wawasan Persatuan Muballigh Kota Batam dalam merefleksikan cita-citanya senantiasa menyesuaikan diri dengan perkembangan dunia.

2. Gambar pelangi melambangkan bahwa persatuan Muballigh Kota Batam di tengah masyarakat sekaligus dimaksudkan kehadirannya maupun membuat situasi menjadi indah dan damai.

3. Gambar kitab Al-Qur'an terbuka melambangkan gerakan Persatun Muballigh Kota Batam adalah menegakkan amal ma'ruf nahi munkar.

21 Wawancara, Hamdan, (Sekretaris PMB Kecamatan Sekupang), periode 2014-2017.
4. Gambar laut melambangkan cita-cita ideal Persatuan Muballigh Kota Batam untuk mewujutkan masyarakat sejatra lahir dan batin suasana madani dan penuh peradaban.

5. Gambar peta Batam melambangkan bahwa Persatuan Muballigh Kota Batam merupakan organisai lokal yang memposisikan diri sebagai mitra daerah dalam mengembangkan kemajuan Batam.

6. Warna putih di dalam lambang melambanggkan kesucian dalam mencapai visi dan misi Persatuan Muballigh Kota Batam.

7. Warna hijau di dalam lambang melambanggkan kesubutran dan kesejatraan yang menjadi cita-cita Persatuan Muballigh Kota Batam.

8. Warna kuning di dalam lambang melambanggkan kejayaan dan kemenangan yang menjadi target Persatuan Muballigh Kota Batam dalam mencapai maksud dna tujuan.

9. Warna merah di dalam lambang melambanggkan keberanian menjadi modal dasar Persatuan Muballigh Kota Batam dalam mengembangkan tugastugasnya.

10. Warna hitam di dalam lambang sebagai keteguhan dan kesungguhan sebagai sikap Persatuan Muballigah Kota Batam menghadapi persoalan yang dihadapi

Jika dilihat dari nilai-nilai yang menjadi tujuan dari berdirinya organisasi tersebut di antaranya, Berdasarkar landasan filosifis di atas maka PMB kota Batam diibaratkan Pelangi, dalam artian PMB bergerak tidak hanya mengatas namakan sebuah organisi, akan tetapi semua organisasi keislaman baik itu golangan Nahdhatul Ulama (NU), Muhammadiyah, Tarbiyah, al-Washliyah maupun dari keorganisasian lainnya selagi sesuai dengan prinsip ablussunnab waljama'ah maka ia diterima untuk berkecimpung di 
dalam Persatuan Muballigh Kota Batam. Kemudian secara kenggotaan PMB hari ini memiliki kurang lebih 1000 orang muballigh dengan menyesuikan jumlah masjid, mushalla yang ada di kota Batam yaitu kurang lebih 1000 buah. Kehadiran PMB di kota Batam sangat di apresiasi oleh pemerintah dan masyarakat, hal ini dibuktikan dengan adanya perhatian dari pemerintah dengan memberikan honor sebesar 400.000 perbulan dari Pemkot Batam bagi anggota muballigh yang memang belum PNS atau terkait honorer dengan instansi pemerintah lainya. ${ }^{22}$

Kedua, toleransi Ekstrnal. Ada beberapa peran PMB dalam hal toleransi antar agama. Pertama, Sebagai penjelas dalam rangka mengcover isu-isu yang sedang berkembang. Kehidupan majemuk adalah kehidu-pan yang menyatukan berbagai perbedaan. Karena itu tidak jarang dijumpai hal-hal yang dapat memicu pertentangan dan menjurus kepada perpecahan. Tugas PMB di sini adalah mencari informasi sedetailmungkin lalu menjelaskan kepada masyarakat luas melalui ceramah-ceramah, khutbah baik yang disampaikan di hari Jumat maupun hari-hari besar lainnya ataupun apapun kesempatannya sehingga potensi konflik yang mulai terbuka dapat diredam. ${ }^{23}$ Tapi tentu saja selama isu-isu intoleran masih dalam tahap dapat ditoleransi. Dalam hal-hal yang sudah dianggap di luar batas toleransi, PMB akan memperakarsai untuk dilaporkan ke pihak kepolisian dan pengadilan. Sebagai contoh, pernah ada salah seorang tokoh agama lain membuat buku yang menistakan agama Islam. Maksudnya menistakan Islam dengan cara mencampurkan ajaran Islam dengan

22 Wawancara, Hamdan, (Anggota Persatuan Muballigh Kota Batam), tanggal 27 Oktober 2019.

23 Wawancara, Ustaz Zaini Cholish, S.HI (Ketua PMB Kec. Sekupang), 2017-2020. ajaran agama lain. Dalam kasus ini memang PMB tidak dapat menerima sikap intoleransi tokoh agama tersebut. Oleh sebab itu kasus itu kemudian dilaporkan kepada pihak kepolisian dan diproses secara hukum. ${ }^{24}$ Sikap itu tidak dapat diartikan bahwa PMB intoleransi. Justru dengan melakukan hal itu untuk meredam gejolak yang akan timbul di tengah masyarakat. Dapat dibayangkan bila isu itu menjadi bola liar tanpa dapat dikendalikan dan tentu saja akan menjadi alarm bahaya bagi Kota Batam. Di sinilah peran penting PMB. ${ }^{25}$

Kedua, Masuk ke lembaga atau forum antar umat beragama. PMB juga berperan dalam toleransi beragama dengan memasuki lembaga-lembaga atau forum antar agama. Sebagai contoh, Forum Komunikasi Umat Beragama (FKUB) sejak pertama kali didirikan di Kota Batam lansung diketuai oleh pendiri PMB Kota Batam, Didi Suryadi. Preode ketiga (2017-2020) juga diketuai oleh salah satu pendiri PMB, Dr. Ir. Chablullah Wibisono. Begitu juga anggotaanggotanya yang sebagiannya adalah anggota PMB. ${ }^{26}$ Berkiprah dalam form semacam ini tentu saja memainkan peranan penting bagi kerukunan umat beragama. Apa yang penting dari forum ini adalah dapat menjalankan hukum mengenai persoalan rumah ibadah. Pendirian rumah ibadah, misalnya, bila masjid akan didirikan tentu harus sesuai dengan persyaratan SKB 2 Menteri, yaitu 90 orang peserta dan 60 orang pendukung. Demikian juga gereja dan rumah-rumah ibadah umat lainnya, menurut Chablullah, bila pendirian rumah ibadah sudah sesuai dengan syarat-syarat yang

24 Wawancara, Zulkarnaen Umar, MH, tanggal 28 Oktober 2019.

25 'Zulkarnaen Umar, MH'.

26 Wawancara, Dr. Chablullah Wibisono, tanggal 25 Oktober 2019. 
ditentukan tentu tidak akan dihalanghalangi. ${ }^{27}$

Ketiga, Anggota PMB berusaha menjadi tauladan di lingkungannya. Di manapun anggota PMB berdomisili, harus berusaha menjadi contoh atau panutan di kalangan masyarakat sehingga segala persoalan yang menjadi isu sensitif yang berkembang tengah masyara-kat bisa tersaring secara natural sehingga tidak menimbulkan gejolak di tengah masyarakat, dalam hal ini PMB berusaha menjadi penjeles di tengah masyarakat sehingga tidak terjadi kerancuan dalam berpemahaman dalam rangka menghadapi masyarakat kota Batam yang majemuk. ${ }^{28}$

Dengan menerapkan sikap toleransi yang bertujuan untuk mewujudkan sebuah persatuan di antara sesama manusia dan warga negara Indonesia khususnya, tanpa mempermasalahkan latar belakang agamanya. Seluruh agama yang di muka bumi mengajarkan tentang kebaikan, tidak ada yang mengajarkan untuk berbuat kerusakan atau kejahatan. Demikian juga dengan hidup rukun damai, hidup berdampingan dengan agama lain, atau dikenal dengan sikap toleransi.

\section{KESIMPULAN}

Dari gambaran di atas, dapat disimpulkan bahwa tolerasnsi merupakan bagian dari ajaran agama Islam yang perlu menjadi pegagang dalam kehidupan sosial. Toleransi telah diajarkan dalam Islam melalui dalil-dalil nash yang jelas dan contoh sikap toleransi juga telah banyak dipraktikan oleh kalangan salaf. Sedangkan Persatuan Muballigh Batam (PMB) merupakan organisasi yang beranggotakan para mubalig

27 'Dr. Chablullah Wibisono'.

28 Wawancara, Suyono Wakil Ketua Umum Persatuan Mubaligh Kota Batam, tanggal 23 Oktober 2019. di Batam dengan ketentuan khusus namun tidak mengikat dari ragam organisasi keagamaan Islam yang telah ada, seperti Nahdlatul Ulama, Muhammadiyah, Tarbiyah, al-Washliyah dan lainnya. Dalam ketentuan organisasi, setiap anggota harus mengikuti ketentuan dan program yang telah ditetapkan dan menjadi tauladan di lingkungannya serta berpikir moderat. Secara organisasi, PMB juga turut berperan dalam kegiatan lintas organisasi dan lintas keagamaan untuk turut menciptakan kehidupan yang toleran di Batam. Sebab, Batam sebagai kota metropolitan yang berpenduduk sangat plural dengan beragam suku dan agama. Dalam kondisi seperti itu, PMB Batam mengambil posisi untuk menciptakan suasana damai dan tenteram dengan selalu memberikan masukan kepada pihak-pihak terkait apabila ditemukan permasalah intoleransi keagamaan di Batam.]

\section{DAFTAR PUSTAKA}

Abidin, Ahmad Zainal, 'Piagam Nabi Muhammad Saw: Konstitusi Negara Tertulis Yang Pertama Di Dunia', Jakarta: Bulan Bintang, 1973

Ali, Atabik, and Ahmad Zuhdi Muhdlor, Kamus Kontemporer Arab-Indonesia (Yayasan Ali Maksum, 1996)

Arnold, Thomas, The Preaching of Islam: $A$ History of the Propagation of the Islamic Faith (Lahore: Sh. Muhammad Ashraf, 1961)

Duncan, Alistair, The Noble Sanctuary (London: Longman Group, 1972)

Ghazali, Abd Moqsith, Argumen Pluralisme Agama: Membangun Toleransi Berbasis alQur'an (Kata Kita, 2009)

Ghazali, Adeng Muchtar, 'Toleransi Beragama Dan Kerukunan Dalam Perspektif Islam', Religious: Jurnal Studi 
Agama-Agama Dan Lintas Budaya, 1.1 (2016), 25-40 $<$ https://doi.org/10.15575/rjsalb.v1i $1.1360>$

Haryono, Daniel, Kamus Besar Bahasa Indonesia Edisi Terbaru (Jakarta: PT Media Pustaka Phoenix, 2012)

Hasyim, Umar, Toleransi Dan Kemerdekaan Beragama Dalam Islam Sebagai Dasar Menuju Dialog Dan Kerukunan Antar Agama: Sejarah Tolerasi [Ie Toleransi Dan Intoleransi Agama Dan Kepercayaan Sejak Jaman Yunani (Bina Ilmu, 1979)

Hisyam, Ibn, Sirah Al-Nabi (Beirut: Dar Ihya al-Turas al, Arabiyy, t.t)

'Https://Batam.Go.Id/Profil/Sejarah', 2019 'Https://Www.Seputar Pengetahuan.Co.Id' Ismail, Moh, 'Kritik Atas Pendidikan Toleransi Perspektif Multikulturalisme', At-Ta'dib, 7.2 (2012)

J. Suyuthi, Pulungan, Prinsip-Prinsip Pemerintahan Dalam Piagam Madinah: Ditinjau Dari Pandangan Alquran (Jakarta: LSIK, 1994)

Khaeruman, Badri, Moralitas Islam (Bandung: Pustaka Setia, 2004)

Misrawi, Zuhairi, 'Al Qur'an Kitab Toleransi: Inklusivisme', Pluralisme Dan Multikulturalisme, (Jakarta Selatan: Penerbit Fitrah. 2007), 2007

Montgomery Watt, William, 'Islamic Political Thought', Edinburgh: Edinburgh University. Translation in French (1995), La Pensée Politique de l'islam. Paris: PUF, 1968

'Persatuan Muballigh Kota Batam', Wikipedia bahasa Indonesia, ensiklopedia bebas, 2019 $<$ https://id.wikipedia.org/w/index.p hp?title=Persatuan_Muballigh_Kota_ Batam\&oldid $=15222609>$ [accessed 4 September 2020]
Sarapung, Elga, 'Pluralisme, Konflik Dan Perdamaian', Yogyakarta: Pustaka Pelajar, 2002

Sukardja, Ahmad, Piagam Madinah Dan Undang-Undang Dasar 1945: Kajian Perbandingan Tentang Dasar Hidup Bersama Dalam Masyarakat Yang Majemuk (Penerbit Universitas Indonesia, 1995)

Thoha, Anis Malik, Tren Pluralisme Agama: Timjauan Kritis (Gema Insani, 2005)

Wawancara, Dr. Chablullah Wibisono, 2019

—, H. Khudhry Syam, (Salah Seorang Pendiri PMB), 2019

- Hamdan, (Anggota Persatuan Muballigh Kota Batam), 2019

-, Hamdan, (Sekretaris PMB Kecamatan Sekupang), 2017

-, Maryonono (Ketua Persatuan Muballigh Kota Batam), 2019

, Sudirman Dianto (Sekretaris PMB kota Batam), 2019

—, Suyono Wakil Ketua Umum Persatuan Mubaligh Kota Batam, 2019

—, Ustaz Zaini Cholish, S.HI (Ketua PMB Kec. Sekupang), 2017 , Zulkarnaen Umar, MH, 2019

, Zulkarnaen Umar, MH , (Ketua Umum PMB), 2014 